\title{
Exercise and Dietary Restriction for Promotion of Neurohealth Benefits
}

\author{
Trevor Archer1,2, Danilo Garcia ${ }^{2,3}$ \\ ${ }^{1}$ Department of Psychology, University of Gothenburg, Gothenburg, Sweden \\ ${ }^{2}$ Network for Empowerment and Well-Being, University of Gothenburg, Gothenburg, Sweden \\ ${ }^{3}$ Institute of Neuroscience and Physiology, Centre for Ethics Law and Mental Health (CELAM), University of \\ Gothenburg, Gothenburg, Sweden \\ Email: trevor.archer@psy.gu.se, danilo.garcia@icloud.com
}

Received 24 December 2014; accepted 9 January 2015; published 20 January 2015

Copyright (C) 2015 by authors and Scientific Research Publishing Inc.

This work is licensed under the Creative Commons Attribution International License (CC BY).

http://creativecommons.org/licenses/by/4.0/

cc) (i) Open Access

\begin{abstract}
Physical exercise, whether aerobic, endurance or resistance types, plays a central role in establishing and maintaining the integrity of the brain and central nervous system (CNS). When exercise is adhered to in conjunction with selective food/drink intake and dietary restriction, it promotes neurohealth. In this article, we review the interactions of age and gender, as well as insulin and diabetes, with exercise, individuals' cognitive-affective status and its interactions with exercise propensity, all of which modulate the eventual outcomes of the influence of exercise upon parameters of neurohealth. The combination of exercise with dietary restriction provides numerous factors pertaining to psychological, neurochemical and anti-pathological manifestations of neurophysiological resilience even through aging. The challenge evoked by the exercise-diet combination in the body mobilizes a multitude of adaptive cellular stress-response signaling pathways in neurons involving neurotrophic factors, anti-inflammatory cytokines, DNA-repair proteins, macroautophagy, and mitochondrial biogenesis.
\end{abstract}

\section{Keywords}

Exercise, Diet, Neurohealth, Insulin, Cognition, Affect, Brain

\section{Introduction}

Any bodily activity that enhances or maintains physical fitness implies the involvement of regular and frequent exercise. Morris and Schoo [1] have defined exercise as a planned, structured physical activity with the purpose of improving one or more aspects of physical fitness and functional capacity. Obesity and overeating combined 
with a sedentary lifestyle is associated with a wide range of health problems, not least with regard to the brain and CNS structure and functioning, that include neuroimmune inflammatory complications, neurodegenerative disturbances, cognitive dysfunctioning, diabetes type II, regional brain dysconnectivity, surgency and negative affectivity among children and food addiction [2]-[5]. For instance, metabolic dysregulation is implicated in Alzheimer's disease [6]. Both physical exercise and intermittent dietary restriction (DR) mobilize adaptive cellular stress response signaling pathways in neurons involving neurotrophic factors, protein chaperones, DNArepair proteins, autophagy and hormesis, and cerebral ischemia and mitochondrial biogenesis [7] [8] whereas overeating and a sedentary lifestyle suppress adaptive cellular stress responses thereby promoting the risk of neurodegenerative disorders, attention-deficit and hyperactive disorder, stroke, immunosenescence and depression [9]-[16] and dietary restriction [17] stimulated mitochondrial biogenesis. Lack of exercise, combined with an overweight and overeating condition, is associated with several variations of neurotoxicity and neurodegenerative conditions [18]-[20]. The hippocampal region of the brain seems particularly sensitive to conditions of illhealth, such as diabetes and overeating. Patients presenting these conditions of illhealth show smaller hippocampi and experience a greater degree of cognitive decline than individuals without these co-morbidities [21].

\section{Age, Gender and Exercise}

The brain and peripheral aging processes are accelerated by high levels of energy accumulation accompanied by low levels of energy expenditure and energy restriction [22] [23]. Insulin resistance, a physiological condition through which cells fail to respond to insulin and its effective use, leads to hyperglycemia which in turn results increased pancreatic insulin production, hyperinsulinemia. Insulin resistance is elevated by age, obesity, adiposity and a sedentary lifestyle [24]; these conditions present risk factors for cognitive dysfunction and both earlyonset and late-onset Alzheimer's disease [25]-[29]. De la Monte and Tong [30] have outlined the various influences of aging, lifestyle choices and predispositions, peripheral insulin resistance diseases, such as obesity, type II diabetes, nonalcoholic fatty liver disease and metabolic syndrome, nitrosamine exposure and familial genetic/ epigenetic mediators of brain loss of integrity, deficits of cognitive, motor and affective domains and neurodegeneration. Hyperphagia and obesity potentiate oxidative reactive species production chronic hyperglycemia accelerating the formation of advanced glucose end products in (pre)diabetes with both mechanisms driving a neurodegenerative outcome. Obesity, insulin resistance and sedentary habits are linked to a greater risk for Parkinson's disease [31]-[33]. Furthermore, obesity appear to endower greater vulnerability to the destructive actions of neurotoxins and stress: Bousquet and colleagues [34] have shown that the exposure of adult C57BL/6 mice to a high-fat diet exacerbated the effects of the dopamine neurotoxin, MPTP, on the decreased number of nigral tyrosine hydroxylase- and dopamine transporter-expressing neurons (23\%) in the striatum and dopamine levels (32\%), indicating that diet-induced obesity is associated with a reduced capacity of nigral dopaminergic terminals to cope with MPTP-induced neurotoxicity (see alsoMattson [35] (2014) who has outlined a comprehensive review of the advantages of lifestyle interventions (exercise) and energy expenditure, rather than accumulation (dietary restrictions), for the prevention and treatment of Parkinsonism).

The introduction of exercise regimes has been found beneficial both under laboratory and clinical conditions; this observation is particularly evident with consideration of various health biomarkers. In aged male rats (20-month-old, known for their obesity under sedentary conditions), treadmill exercise attenuated age-related cognitive decline in the inhibitory avoidance test, reduced pro-inflammatory biomarkers, TFN- $\alpha$ levels, and elevated histone $\mathrm{H} 4$ acetylation levels, associated with enhanced transcriptional activity related to improved epigenetic outcome, in hippocampal tissue [36]. In addition, Zhang and colleagues [37] obtained a positive association between physical exercise and global genomic DNA methylation in a cancer-free population. Exercise utility has been examined in wide range of inflammatory conditions [38]. The epigenetics of health benefits arising from regular physical exercise is being pursued [39]. Furthermore, running exercise, through amplification of galanin expression in noradrenergic locus coeruleus neurons and suppression of stress-induced activity of the locus coeruleus and noradrenaline output in locus coeruleus-target regions, induces an adaptive response to stress thereby relieving anxiety-like behaviors in a manner dependent on stress [40]. The effects of physical exercise, 6 weeks of voluntary running wheel activity, in male Wistar rats prior to colitis-induction using trinitrobenzene sulphonic acid challenge was assessed in a study by Szalai and colleagues [41]. They measured colonic gene (TNF- $\alpha$, IL-1 $\beta$, CXCL1 and IL-10) and protein (TNF- $\alpha$ ) expressions of various inflammatory mediators and enzyme activities of heme oxygenase (HO), nitric oxide synthase (NOS), and myeloperoxidase (MPO) 
enzymes. It was observed that the activities of HO, constitutive NOS (cNOS) isoform were increased. The exercise regime decreased significantly TNBS-induced inflammatory markers, including extent of lesions, severity of mucosal damage, and gene expression of IL-1 $\beta$, CXCL1, and MPO activity whereas IL-10 gene expression and cNOS activity were elevated; iNOS activity was reduced and the activity of HO enzyme increased in comparison with the sedentary TNBS-treated group. Thus, the anti-inflammatory role of exercise through 1) downregulation of pro-inflammatory mediator gene expression, 2) induction of anti-inflammatory mediators, and 3) modulation of $\mathrm{HO}$ and NOS enzyme activity.

\section{Insulin, Diabetes and Exercise}

Physical exercise influences cognitive, emotional, learning and neurophysiological domains, both directly and indirect, thereby rendering it essential that this noninvasive, non-pharmacological intervention ought to form a part of children's and adolescents' long-term health programs [42]. Some evidence suggests that neurotoxicity/neuropathy may be greater in individuals presenting diabetic conditions [43]-[45]. In juvenile and adolescent populations, physical exercise holds benefits in association with the health of bones, cardiovascular fitness, healthy blood lipid profiles, psychological well-being and is linked inversely to levels of adiposity and stress [46]. Nevertheless, the prevailing situation among youth populations suggested that these benefits are largely unrealized: the 2011 Centers for Disease Control and Prevention Youth Risk Behavior Surveillance System implies that only $28.7 \%$ of healthy high school pupils showed physical activity levels that reached the Federal guideline of 60 min moderate-to-vigorous intensity physical exercise, much less among those presenting chronic disorders, such as type I diabetes [47] [48]. Fear of hypoglycemia among adolescent type I diabetics induces low levels of exercise although this activity is an important aspect of disease management [49] [50]. Nevertheless, physical exercise provides a recipe for glycemic control among these patients [51]-[53]. In a study of 19 type I diabetics aged 14 - 20 years, with average fitness, and adiposity, meeting the Federal guideline of 60 min daily moderate-to-vigorous intensity physical exercise, Metcalf and colleagues [54] observed that hypoglycemia was $31 \%$ more likely among those adolescents who had accumulated 30 minutes/day more moderate-to-vigorous intensity physical exercise in the previous afternoon than those who had accumulated less. Thus, the authors propose that in the promotion of exercise type I diabetic adolescents ought to be informed on hypoglycemia prevention (cf. [55] [56]).

Patients presenting type I diabetes mellitus with insulin dependence are at risk for autonomic/central neuropathy and/or cardiovascular dysregulation and coronary heart diseases [57]-[59], particularly in children [60]. Abnormal cardiac ANS functioning and cardiac autonomic neuropathy has been observed in children with type I diabetes [61]-[63]. Heart rate variability reduction linked to diabetes provides an early symptom of neuropathy [64]. Increased physical exercise in type I diabetic children was associated with lower diastolic blood pressure, lower lipoprotein levels and better glycemic control [65]. Leggio and colleagues [66] have shown the positive impact of exercise training on both left and right ventricular systo-diastolic function. It has been observed too that physically active type II diabetics over the life-long cycle presented superior fitness levels, lower homeostatic model assessment-insulin resistance (HOMA-IR) and cardiovascular risk, and higher brachial artery flowmediated dilation compared to sedentary peers, whilst no differences were found when compared to controls. In a study of fifteen type I diabetes boys given treadmill exercise 3 days/week over 12 weeks, Shin and colleagues [61] obtained total and low-frequency power of heart rate variability increases and lower total cholesterol levels. Total and high-frequency power of heart rate variability were correlated with higher cholesterol levels although diastolic blood pressure and low-frequency power of heart rate variability were correlated with lower total cholesterol levels. The authors prescribed physical exercise interventions for children with type I diabetes.

\section{Cognitive-Affective Status and Overeating}

Much evidence supports the notion that disruptions in emotional regulation affect the maintenance of emotional overeating and eating pathology in obese adults with binge eating disorders [67], not least in context of "emotional eating” [68]. Brownstone and colleagues [69] observed that subjective binge eating, as opposed to objective binge eating, accounted for the unique variance within weight/shape concern, diuretic use frequency, depressive symptoms, anxiety, social avoidance, insecure attachment, and cognitive distortion. Patients with type II diabetes mellitus were reported to be more likely to be afflicted by severe depression than patients without the diabetes disorder while depression by itself was not an independent predictor of diabetes control [70]. Roberts 
and colleagues [71] have shown that midlife onset of diabetes type II may influence late-life cognitive performance through loss of brain volume and midlife hypertension may impair executive function through ischemic neuropathology. Berg and colleagues [72] have observed that negative affect seems to occur as an antecedent to "overeating without loss of control" and "binge eating" episodes thereby suggesting the necessity of focusing upon "affective-shift". Negative affect was found to modulate impulsiveness and impulse control in choice behavior, with or without punishment/reward, in 59 women afflicted by bulimia nervosa or binge eating disorder and 30 controls [73]. Their results showed that negative affect influenced choice behavior differently in healthy controls and in women with bulimia nervosa and binge eating disorder following punishment (but not after reward) whereby choice behavior deteriorated in the former under negative affect but not the latter (controls). Trait-impulsivity among food-craving women was shown to determine also the efficacy of a transcranial direct current stimulation intervention on impulsive choice behavior [74]. The notion of Chronic Positive Energy Balance (CPEB), derived from epidemiological, clinical and animal laboratory studies, applies to impairments in structure and function in brain regions regulating emotional and cognitive control. For example, higher BMI, in a study of 36 healthy adults, was linked to reduced cerebral blood flow in prefrontal cortical regions involved in executive functioning [75]. Human and animal notions of emotional or stress-induced eating appear to provide a convergence of genetic predispositions, such as impulsivity and reward sensitivity, and neurohumoral dysregulation, dopamine-serotonin-noradrenaline, thereby affecting incentive salience. "Comfort-eaters" show vulnerability to depression, emotional dysregulation and a need to escape negative affect and rumination. When overcome by negative affect, they preferentially consume sweet, fatty, energy-dense food, which may confer protection against stress, as expressed by suppression of the hypothalamic-pituitary-adrenal axis response, although activation of the hypothalamic-pituitary-adrenal axis may itself drive appetite for these palatable foods, and the risk of weight gain is increased [76].

The affective domain presents a frequently studied issue within physical exercise interventions not least since the ability and capacity to interact with other individuals modulates the positive interaction with oneself thereby placing a premium on high levels of positive affect by presenting the conditions for developing personal characteristics and delivering affective qualities [77]. Studies, undertaking to explore the cognitive-emotional profiles of individual expressing disorders of binge and overeating, have observed relationships between the Big Five dimensions of personality, dietary intake, ability to undertake dietary restrictions and compliance to dietary recommendations. Different ethnical and cultural cross-sectional surveys have demonstrated a positive association between "Openness" and consumption of fruits and vegetables as well as between "Conscientiousness" and healthy eating habits [78]. Nevertheless, there seems little evidence that personality dimensions per se are linked with adherence to dietary recommendations over time, "Conscientiousness" was associated with a number of pro-social and health-promoting behaviors that included avoidance of alcohol-related harm, binge-drinking, and smoking, and adherence to medication regimens accompanied by the link between higher Conscientiousness and lower obesity risk. In a Korean study of BMI and personality traits [61], gender differences seem to define the observed relationships: in male subjects, overweight and obese men obtained higher scores on "openness to experience" and lower scores on "conscientiousness" whereas overweight and obese women had lower scores on "neuroticism" and "openness to experience" and higher scores on "agreeableness". In the male participants, BMI was related positively extraversion with BMI and waist circumference measure more related to less dutiful individuals whereas, in women, "neuroticism" and "openness to experience" was negatively associated with BMI which was positively associated with agreeableness and waist circumference. Dispositional impulsivity, which is associated routinely with high-risk behavioral tendencies, including addictive consumption of, sex, alcohol and drugs, seems to present an important risk factor in considerations of predispostions towards the engagement in addictive consumption of food [79]. They obtained positive associations between facets of impulsiveness, food addiction symptoms, and BMI while impulsiveness was related indirectly with BMI through links with addictive consumption of food. There was an inclination toward behaving irrationally while experiencing negative mood states, "Negative Urgency", and low levels of task persistence, "lack of Perseverance", were linked with food addiction directly and relevant for the expression of BMI. Temperament and character factors have been shown also to be related to BMI, obesity and eating disorders [80].

\section{Exercise and Neurohealth}

Although the neuroprotective and neuroreparative effects of physical exercise have been documented consis- 
tently, particular in neurodegenerative disorder conditions [81] [82], the antineurotoxic influences of this intervention are not obvious: chronic treadmill running exercise induced purkinje cell toxin resistance in the cerebellum and improved the motor performance of rats [83] but six weeks of voluntary exercise did not produce any anti-neurotoxic effect against MPTP and MPP+ toxicity [84]; nor did 90 days of unrestricted running exercise prevent MPTP-induced neurotoxicity in BDNF haploinsufficient mice [85]. Nevertheless, Hosseinzadeh and colleagues [86] showed that lead acetate-induced increase in plasma and hippocampal malondialdehyde and reduction in hippocampal BDNF and total antioxidant capacity was reduced and elevated, respectively, by eight weeks of treadmill running ( 5 times/week). In an animal model of $\mathrm{AD}$, two-month old male C57bl/6 mice were injected intracerebroventricularly with $\mathrm{A} \beta 25-35$, and then given access to voluntary exercise for 12 days followed by test of cognitive performance in a Y-maze [87]. The A $\beta 25$-35-treated mice with access to exercise displayed reduced neuronal degeneration and synaptic protein loss in the hippocampus compared with sedentary controls as well as an amelioration oxidative stress markers and increased vessel branches in the hippocampus region. Thus, the exercise regime here reduced oxidation stress and increased angiogenesis both expressing antineurotoxic influences. Running wheel exercise over two weeks prevented in a marked fashion the development of L-DOPA-induced dyskinesia in 6-hydroxydopamine hydrochloride-hemiparkinsonian mice [88]. Trimethyltin presents a chemical-induced model of hippocampal dentate granule cell death; two weeks of running exercise attenuated neuronal death and diminished elevations in $\mathrm{TNF} \alpha$, TNF receptor 1 , myeloid differentiation primary response gene (MyD) 88, transforming growth factor $\beta$, chemokine (C-C motif) ligand 2 (CCL2), monocyte chemotactic protein-1, and CCL3, microphage inflammatory protein-1 $\alpha$, both the latter are involved in the acute inflammatory state following tissue damge/infection [89].

The health benefits accruing from regular exercise are manifest: it reduced inflammatory cytokines (CPR and Il-6) in patients with type II diabetes [90]. In healthy individuals, physical exercise programs incorporating 30-min sessions 3 times/per week were linked with consistent improvements in health status variables [91]. Regular physical exercise/exertion promotes neuroimmune functioning and facilitates prevention of heart conditions, cardiovascular diseases, type II diabetes and obesity, and mental health improvements, e.g., depressiveness, all of which may exacerbate the Parkinson's disease condition [92] [93]. The types of exercise relevant here have been characterized on the basis of type, intensity, frequency, and duration, with either endurance or resistance capacity as the training endpoint [94]. Endurance exercise develops one's ability to exert oneself over long periods of physical activity whereas resistance exercise implies exerting resistance to the force of muscular contraction and elastic or hydraulic resistance, a specific type of strength training that utilizes elastic or hydraulic tension to provide this resistance [95]. Physical exercise has been manifested in marked improvements both in function and biomarker integrity [96]-[101]. Ang and colleagues [102] have indicated that neuroprotection following physical exercise may be the consequence of elevated levels of an endogenous neurotrophic factor/nerve growth factor and the proliferation of its receptive cholinergic neurons thereby endowering long-term health advantages [103]. Thus, the benefits of regular physical exercise as a health-ensuring necessity over age, gender, occupation and affective status cannot be overestimated [104] [105].

Excess body weight and adiposity induces insulin resistance, inflammation and neuroimmune functional deficits, and various other alterations in metabolic and neurohormonal factors that promote atherosclerosis, tumorigenesis, neurodegeneration, and accelerated aging [106]. Contrastingly exercise (treadmill running, 20 metres/ min, $90 \mathrm{~min}$ ) increased insulin sensitive in C57BL6J mouse skeletal tissue through a mechanism involving accumulation of M2-polarized macrophages [107]. In the current reality of aging and/or obese populations, economic and resource-availability reductions and deterioration in personal health through overweight and obesity, even the health status of caregivers ought to be assessed in the interests of future health prognoses. In children and adolescents, a small to moderate effect was obtained with regard physical exercise training on fasting insulin and improving insulin resistance in juveniles [108]. Loi and colleagues [109] have identified and examined studies carried out between 1975 and 2012, involving female Caucasian caregivers older than 60 years. Despite small sample sizes, preponderance of short-term rather than long-term follow-ups, and varying results that limited generalizability, they concluded that physical exercise interventions improved stress experience, depression and caregiver burden. Napoli and colleagues [110] studied 107 frail, obese older adults were randomly assigned to a control, weight-management (diet), exercise group or to a weight-management-plus-exercise (dietexercise) group for a period of 12 months, with outcome measures: Modified Mini-Mental State Examination, total Impact of Weight on Quality of Life-Lite scores, the Word Fluency Test, Trail Making Test Parts A and B, and the Geriatric Depression Scale, a combination of affective status, cognitive functioning and quality-of-life 
assessments. They found that exercise and weight loss alone provided improved improvements in affect, cognition and life quality although combination, exercise + diet, may have induced benefits comparable to exercise alone. It has been shown that, using an oral glucose tolerance text as index of insulin sensitivity, assessing insulin resistance, in obese adults [111], regular exercise was accompanied by persistent improvements in insulin sensitivity that lasted at least 3 days after exercise whereas just one session of exercise elevated insulin sensitivity among the individuals to levels equivalent to the regular exercisers. Insulin resistance, implicated in the pathophysiology of diabetes is associated with obesity, cardiovascular risk factors and derangement of brain and CNS integrity. Systemic low grade inflammation linked to obesity accelerates immunosenescence and skeletal muscle decline [112]-[114]. Twelve months of progressive resistance training in older adults with type II diabetes induced increments in skeletal muscle mass, reduced C-reactive protein and adiposity [115].

Many of the health benefits associated with physical exercise overlap with the neuroprotective functions of the cellular pathway of macroautophagy [116] [117], a multistep vacuolar degradation process signaling events that occur upstream of the molecular machinery of autophagy and molecular machinery involved in the formation of the autophagosome, the initial multimembrane-bound compartment formed in the autophagic pathway [118]. Autophagy is the process of self-digestion by cells through the actions of enzymes originating within the same cell thereby presenting an essential homeostatic mechanism by which cells break down their own components. This process is receiving emerging attention in several disorder conditions, including chronic inflammatory diseases, ageing and neurodegenerative diseases and adaptive immunity [119]. One relationship between autophagy and process of related hormesis has been illustrated with regard to ionizing radiation [120]; but there are several others. He and colleagues [121] have shown that some of the health benefits of exercise may be due to autophagy activation in multiple organs participating in metabolic regulation, e.g. muscle and adipose tissue, but also brain regions. They observed that mice with a knock-in nonphosphorylatable mutation in BCL2 (BCL2 AAA mice) were defective in exercise- and starvation-induced autophagy but not basal autophagy. In wild-type, but not BCL2 AAA, mice treadmill exercise induced autophagy in the cerebral cortex by reversing high-fat dietinduced glucose intolerance after 8 weeks of treadmill running and increases in skeletal muscle glucose uptake (see also [122]-[124]). Following 36 weeks of moderate, long-term treadmill exercise, the cortices of exercised rats displayed an inactivation of mTOR, greater autophagy flux of the autophagic proteins Beclin 1, p62, LC3B (increased LC3-II/LC3-I ratio and reduced p62) as well as increased lysosomal protein, LAMP1, but not in the hippocampus [125]. Physical exercise promotes both the longevity and efficacy of the mitochondrial life cycle processes, biogenesis, maintenance and clearance [126]. It has been observed that premature age-related axonal and myelin degenerations, increased autophagy and mitophagy and mitochondrial supercomplex instability preceding degeneration and cell death [127]. It has been shown too that life-long strenuous exercise was linked to increased levels of the aging neuroimmune system biomarkers reduced partially with physiological aging through these interventions [128].

\section{Exercise and Dietary Restriction}

A large variety of neural circuits throughout the brain show higher levels of electrochemical activity during physical exercise and dietary restriction than during the satiated and resting state [129]. In chronic mild stresstreated rats, not only behavioral improvements but also serum corticosterone, serotonin, dopamine and noradrenaline levels in the hippocampus were elevated following exercise [130]. Aged individuals that had undergone an exercise program over four months evidenced elevated hippocampal blood flow and displayed greater hippocampal and anterior cingulate cortex functional connectivity in comparison with age-matched sedentary controls [131]. Neurotrophic factors, including brain-derived neurotrophic factor (BDNF), insulin-like growth factor 1 (IGF-1), vascular endothelial cell growth factor (VEGF), glial cell line-derived neurotrophic factor (GDNF), and fibroblast growth factor 2 (FGF2), are implicated in the adaptive, neuroprotective, neuroreparative and plasticity responses of brain cells to exercise and dietary restriction [132]-[134]. An exercise + dietary (calorie) restriction regime caused synergistic protection against cognitive decline via up-regulation of BDNF in the hippocampus of stroke-prone hypertensive rats [135]. However, alternate-days feeding did not enhance the effects of forced swimming exercise and voluntary exercise upon hippocampal BDNF levels and spatial memory performance in rats [136] [137]. Body-weight-supported treadmill training regime offers a physical exercise intervention in which individuals presenting spinal cord injury (SCI) step on a motorized treadmill while some of the body weight is removed through an upper body harness. This intervention promotes temporal gait parameters, muscle 
activation patterns, and clinical outcome measures, through reorganization that occurs simultaneously in supraspinal and spinal cord neural circuits in spinal cord injury individuals [138]. The influence of personal attributes, such as motivation, character and affective status ought not to be neglected since in a sample of obese adolescents, it was shown that "motivational interviewing" enhanced adherence to this obesity intervention consisting of biweekly dietitian and behavioral support visits and supervised physical activity [139].

In a systematic review of the dietary restriction-physical exercise combination, Kuovelioti and colleagues. [140] identified 14 studies randomized clinical trials that fulfilled all criteria. The overall estimations showed an effective weight loss of $11.1 \mathrm{~kg}$ (about 13\%) from a mean of about 4 months from baseline, a weight loss maintainance of $5.8 \mathrm{~kg}$ (about 52\%) over one year; a weight regain was registered in all 14 studies with an mean of $5.1 \mathrm{~kg}$. Effective weight loss was successful but almost half of it (about $48 \%$ ) was regained. The Jadad score, a procedure to assess independently the methodological quality of a clinical trial, showed very good to excellent quality for all 14 studies. Several studies have supported the use of whey protein, either as a supplement combined with resistance exercise, or as part of a weight loss or weight maintenance diet, to improve body composition parameters [141]. The interactive influence of diet and exercise has led to considerations regarding aspects of neuroimmune functioning: 1) exercise and immunosenescence, 2) acute exercise influences on cellular shifts and gene expression, 3) exercise effects upon neuroimmune regulation under conditions of stress and disease, and 4) the impact of dietary counter measures on immunity during extreme performance [142]. Sylvia and colleagues. [143] investigated the proof of concept of a consolidated program of Nutrition, Exercise, and Wellness Treatment ("NEW Tx") for overweight individuals presenting bipolar disorder. They found that the participants attended most sessions and reported high satisfaction with the treatment. Their weight, cholesterol and trigyclerides decreased over the study duration as well as number of daily calories and sugar intake and weekly exercise duration more than tripled during the duration of the study and depressive symptoms and functioning were improved. EVASYON presents a multidisciplinary treatment program intervention for adolescents with overweight and obesity that is aimed comprising all possibly involved areas of the individual, including dietary habits, physical activity and cognitive and psychological profiles. Garcia-Calzon and colleagues [144] obtained significant increases in telomere length, associated with higher structure and function, in overweight/obese adolescents. Furthermore, the authors imply that initial longer telomere length may offer a potential predictor for a more effective weight loss response.

Aerobic exercise training programs consistent with public health recommendations may promote up to modest weight loss that may improve at-risk individuals' prognosis for diabetes prevention, nevertheless weight loss on an individual basis is highly heterogeneous [145], despite concerns regarding physical exercise guidelines [146]. Systemic and vascular inflammation markers deteriorate with obesity and insulin resistance whereas reductions in plasma sICAM-1, soluble intercellular adhesion molecule-1, improve insulin sensitivity [147]. Higher levels of ICAM-1 are implicated in subarachnoidal hemorrhage [148]. Ryan and colleagues [149] have observed that exercise and weight loss reduced CRP, SAA, and tissue ICAM which indicated that exercise training offered a necessary component of lifestyle modification in obese postmenopausal women. Aguiar and colleagues [150] have indicated that diet and both aerobic and resistance exercise training prevents multi-component lifestyle type II diabetes by inducing weight loss and improving impaired fasting glucose, glucose tolerance, dietary and exercise outcomes in at risk and pre-diabetic adult populations which supports the current exercise guidelines for the inclusion of resistance training in type II diabetes prevention. In a home-based exercise program, mean compliance to the supervised exercise training was $96 \%$ and no adverse effects were reported, while capillary glucose concentration was acutely reduced in response to each cycling session. Overall, the exercise group had lower mean daily postprandial glucose concentrations throughout the intervention compared with the control group despite consuming a greater proportion of dietary carbohydrate [151]. An eight-week aerobic exercise training induced significant effects on mental health, subscales of physical symptoms, and anxiety and insomnia in 53 type II diabetic patients, but produced no significant effects on subscales related to disorder of social functioning and depression [152]. Aerobic exercise training offers as an appropriate program for improving the health of the patients with type II diabetes mellitus, as well as inducing positive effects upon mental health. Thus, musculoskeletal symptoms and functional status of limbs and spine in patients with type II diabetes mellitus were improved in exercise subjects compared with non-exercised control subjects and correlated with PA/exercise volume and improvements in fitness parameters [153]. In a short-term exercise program study involving glycemic levels assessed by fructosamine concentrations in type II diabetes patients, Moura and colleagues [154] obtained reductions in fructosamine and improved glycemic status. Finally, dietary behavior modification, but 
not the exercise intervention, in 68 Swedish women, 14 - 16 weeks postpartum, that produced sustained weight loss among overweight and obese lactating women improved also risk factors for cardiovascular disease and type II diabetes.

A high fat diet is associated with adiposity, glucose intolerance and insulin resistance [155]. Metabolic abnormalities arising from a high fat diet cause platelet hyperaggregability that involves enhanced intraplatelet reactive oxygen species production and decreased (NO)-soluble guanylyl cyclase (sGC) signaling pathway in the platelet bioavailability [156]. A lifestyle combining dietary restriction and regular physical exercise appears to be essential for the integrity of cardiovascular systems [157]. Protein kinase C-beta (PKC $\beta$ ) is an isozyme involved in signal transduction cascades and its expression is decreased in both skeletal muscle and liver tissue following physical exercise. Both exercise and $\mathrm{PKC} \beta$ deficiency may alleviate high fat diet-induced insulin resistance, as shown through improved insulin tolerance [158]. Furthermore, fat accumulation and mitochondrial dysfunction induced by high fat diet were ameliorated also by both exercise and PKC $\beta$ deficiency. Nevertheless, exercise produced marginal effects on PKC $\beta(-/-)$ mice [158]. There was an improved activation of AKT, the "downstream signal" molecule of insulin, in skeletal muscle and liver of exercised mice, whereas PKC $\beta$ deficiency blunted the difference between sedentary and exercised mice. These findings imply that down-regulation of PKC $\beta$ contributes to exercise-induced improvement of insulin resistance in high fat diet-fed mice. Mizutani and colleagues [159] have observed that six days after cerebral infarction in rats the mean latency registered before falling from a rotating rod in the voluntary exercise group was longer than that in the unexercised group. PKC, growth-associated protein 43 (GAP43) and phosphorylated at serine 41 GAP43 (p-GAP43) were increased after voluntary exercise compared with unexercised rats. The expression of PKC immunoreactivity was observed in layer III of the perilesional cortex in exercised rats, and the intracellular localization in the pyramidal neurons was mainly translocated to the plasma membrane. These findings imply that exercise-induced paralysis recovery linked to neuronal plasticity and remodeling of cortical connections through the phosphorylation of GAP43 by interaction with PKC was due to the expression and localization of these proteins. Further, protein expression changes were associated with the underlying mechanisms of exercise-induced paralysis recovery involving neurite formation, and remodeling of synaptic connections may be through the interaction of NGF, calmodulin, PKC and GAP43 [160].

\section{Conclusion}

The present account outlines the undeniable advantages of long-term physical exercise regimes combined with a careful selection of one's dietary schedules over a sedentary life-style accompanied by unrestrictive food consumption. Age, gender and exercise affect neurohealth status by modulating the dynamics of insulin production and mobilization and the pro- and anti-inflammatory cytokines. Several of the brain and CNS problems arising from diabetic conditions may be alleviated by regular physical exercise. Problems arising with inadequate cognitive-affective balance are associated often with nonselective and unrestrictive overeating resulting in poor school, academic and work performance; in children, adolescents and adults, regular physical exercise improved all these aspects of performance, personal attributes pertaining to affect and related biomarkers. Physical activity appears to endower health benefits beyond neuroprotection and neurorestoration of damaged systems; through processes such as macroautophagy and development of neurotrophic factors, it reinforces brain and CNS integrity through preempting diabetes and obesity, cardiovascular risk factors, immunosenescence and skeletal muscle decline thereby delaying or halting the progression of age-related disorders [161] (For further reading see [162][166]).

\section{Acknowledgements}

The development of this article was supported by Bliwa Stiftelsen. The funders had no role in study design, data collection and analysis, decision to publish, or preparation of the manuscript.

\section{References}

[1] Morris, M. and Schoo, A. (2004) Optimizing Exercise and Physical Activity in Older Adults. Butterworth Heinemann, Edinburgh.

[2] Davis, C. (2013) From Passive Overeating to "Food Addiction”: A Spectrum of Compulsion and Severity. International Scholarly Research Notices Obesity, 2013, Article ID: 435027. 
[3] Leung, C.Y., Lumeng, J.C., Kaciroti, N.A., Chen, Y.P., Rosenblum, K. and Miller, A.L. (2014) Surgency and Negative Affectivity, but Not Effortful Control, Are Uniquely Associated with Obesogenic Eating Behaviors among Low-Income Preschoolers. Appetite, 78, 139-146. http://dx.doi.org/10.1016/j.appet.2014.03.025

[4] Miller, A.A. and Spencer, S.J. (2014) Obesity and Neuroinflammation: A Pathway to Cognitive Impairment. Brain, Behavior, and Immunity, 42, 10-21.

[5] Purnell, J.Q., Lahna, D.L., Samuels, M.H., Rooney, W.D. and Hoffman, W.F. (2014) Loss of Pons-to-Hypothalamic White Matter Tracks in Brainstem Obesity. International Journal of Obesity, 38, 1573-1577. http://dx.doi.org/10.1038/ijo.2014.57

[6] de la Monte, S.M. (2014) Relationships between Diabetes and Cognitive Impairment. Endocrinology and Metabolism Clinics of North America, 43, 245-267. http://dx.doi.org/10.1016/j.ecl.2013.09.006

[7] Mattson, M.P. (2012) Energy Intake and Exercise as Determinants of Brain Health and Vulnerability to Injury and Disease. Cell Metabolism, 16, 706-722. http://dx.doi.org/10.1016/j.cmet.2012.08.012

[8] Zhang, Q., Wu, Y., Zhang, P., Sha, H., Jia, J., Hu, Y. and Zhu, J. (2012) Exercise Induces Mitochondrial Biogenesis after Brain Ischemia in Rats. Neuroscience, 205, 10-17. http://dx.doi.org/10.1016/j.neuroscience.2011.12.053

[9] Abbott, R.D., Ross, G.W., White, L.R., Nelson, J.S., Masaki, K.H., Tanner, C.M., Curb, J.D., Blanchette, P.L., Popper, J.S. and Petrovitch, H. (2002) Midlife Adiposity and the Future risk of Parkinson's Disease. Neurology, 59, 1051-1057. http://dx.doi.org/10.1212/WNL.59.7.1051

[10] Archer, T., Fredriksson, A. and Johansson, B. (2011) Exercise Alleviates Parkinsonism: Clinical and Laboratory Evidence. Acta Neurologica Scandinavica, 123, 73-84.

[11] Dempsey, A., Dyehouse, J. and Schafer, J. (2011) The Relationship between Executive function, AD/HD, Overeating, and Obesity. Western Journal of Nursing Research, 33, 609-629. http://dx.doi.org/10.1177/0193945910382533

[12] Donofry, S.D., Roecklein, K.A., Rohan, K.J., Wildes, J.E. and Kamarck, M.L. (2014) Prevalence and Correlates of Binge Eating in Seasonal Affective Disorder. Psychiatry Research, 217, 47-53.

[13] Etemadifar, M., Abtahi, S.H., Abtahi, S.M., Mirdamadi, M., Sajjadi, S., Golabbakhsh, A., Savoj, M.R., Fereidan Esfahani, M., Nasr, Z. and Tabrizi, N. (2012) Hemiballismus, Hyperphagia, and Behavioral Changes Following Subthalamic Infarct. Case Reports in Medicine, 2012, Article ID: 768580.

[14] Fitzpatrick, A.L., Kuller, L.H., Lopez, O.L., Diehr, P., O’Meara, E.S., Longstreth, W.T. and Luchsinger, J.A. (2009) Midlife and Late-Life Obesity and the Risk of Dementia: Cardiovascular Health Study. Archives of Neurology, 66 , 336-342. http://dx.doi.org/10.1001/archneurol.2008.582

[15] Hassing, L.B., Dahl, A.K., Thorvaldsson, V., Berg, S., Gatz, M., Pedersen, N.L. and Johansson, B. (2009) Overweight in Midlife and Risk for Dementia: A 40-Year Follow-Up Study. International Journal of Obesity, 33, 893-898. http://dx.doi.org/10.1038/ijo.2009.104

[16] Konttinen, H., Kronholm, E., Partonen, T., Kanerva, N., Männistö, S. and Haukkala, A. (2014) Morningness-Eveningness, Depressive Symptoms, and Emotional Eating: A Population-Based Study. Chronobiology International, 31, 554-563. http://dx.doi.org/10.3109/07420528.2013.877922

[17] Lettieri Barbato, D., Baldelli, S., Pagliei, B., Aquilano, K. and Ciriolo, M.R. (2012) Caloric Restriction and the Nutrient-Sensing PGC-1 $\alpha$ in Mitochondrial Homeostasis: New Perspectives in Neurodegeneration. International Journal of Cell Biology, 2012, Article ID: 759583.

[18] Ellis, J.M., Wong, G.W. and Wolfgang, M.J. (2013) Acyl Coenzyme A Thioesterase 7 Regulates Neuronal Fatty Acid Metabolism to Prevent Neurotoxicity. Molecular and Cellular Biology, 33, 1869-1882. http://dx.doi.org/10.1128/MCB.01548-12

[19] Morales-Briceño, H., Cervantes-Arriaga, A., Rodríguez-Violante, M., Calleja-Castillo, J. and Corona, T. (2012) Overweight Is More Prevalent in Patients with Parkinson’s Disease. Arquivos de Neuro-Psiquiatria, 70, 843-846. http://dx.doi.org/10.1590/S0004-282X2012001100004

[20] Yamamoto, M., Yanagisawa, R., Motomura, E., Nakamura, M., Sakamoto, M., Takeya, M. and Eto, K. (2014) Increased Methylmercury Toxicity Related to Obesity in Diabetic KK-Ay Mice. Journal of Applied Toxicology, 34, 914923.

[21] Fotuhi, M., Do, D. and Jack, C. (2012) Modifiable Factors That Alter the Size of the Hippocampus with Ageing. Nature Reviews Neurology, 8, 189-202.

[22] Mercken, E.M., Carboneau, B.A., Krzysik-Walker, S.M. and de Cabo, R. (2012) Of Mice and Men: The Benefits of Caloric Restriction, Exercise, and Mimetics. Ageing Research Reviews, 11, 390-398. http://dx.doi.org/10.1016/j.arr.2011.11.005

[23] Spindler, S.R. (2012) Review of the Literature and Suggestions for the Design of Rodent Survival Studies for the Identification of Compounds That Increase Health and Life Span. AGE, 34, 111-120. http://dx.doi.org/10.1007/s11357-011-9224-6 
[24] Tan, E. and Scott, E.M. (2014) Circadian Rhythms, Insulin Action, and Glucose Homeostasis. Current Opinion in Clinical Nutrition and Metabolic Care, 17, 343-348.

[25] de la Monte, S.M. (2014) Relationships between Diabetes and Cognitive Impairment. Endocrinology and Metabolism Clinics of North America, 43, 245-267. http://dx.doi.org/10.1016/j.ecl.2013.09.006

[26] Ferreira, S.T., Clarke, J.R., Bomfim, T.R. and De Felice, F.G. (2014) Inflammation, Defective Insulin Signaling, and Neuronal Dysfunction in Alzheimer's Disease. Alzheimer's Dementia, 10, S76-S83. http://dx.doi.org/10.1016/j.jalz.2013.12.010

[27] Morabito, M.V., Berman, D.E., Schneider, R.T., Zhang, Y., Leibel, R.L. and Small, S.A. (2014) Hyperleucinemia Causes Hippocampal Retromer Deficiency Linking Diabetes to Alzheimer's Disease. Neurobiology of Disease, 65, 188-192. http://dx.doi.org/10.1016/j.nbd.2013.12.017

[28] Steculorum, S.M., Solas, M. and Brüning, J.C. (2014) The Paradox of Neuronal Insulin Action and Resistance in the Development of Aging-Associated Diseases. Alzheimer's Dementia, 10, S3-S11. http://dx.doi.org/10.1016/j.jalz.2013.12.008

[29] Talbot, K. and Wang. H.Y. (2014) The Nature, Significance, and Glucagon-Like Peptide-1 Analog Treatment of Brain Insulin Resistance in Alzheimer's Disease. Alzheimer's Dementia, 10, S12-S25. http://dx.doi.org/10.1016/j.jalz.2013.12.007

[30] de la Monte, S.M. and Tong, M. (2013) Insulin Resistance and Metabolic Failure Underlie Alzheimer Disease. In: Farooqui, T. and Farooqui, A.A., Eds., Metabolic Syndrome and Neurological Disorders, John Wiley \& Sons, New York, 1-30. http://dx.doi.org/10.1002/9781118395318.ch1

[31] Ashrafian, H., Harling, L., Darzi, A. and Athanasiou, T. (2014) Neurodegenerative Disease and Obesity: What Is the Role of Weight Loss and Bariatric Interventions? Metabolic Brain Disease, 28, 341-353. http://dx.doi.org/10.1007/s11011-013-9412-4

[32] Cereda, E., Barichella, M., Pedrolli, C., Klersy, C., Cassani, E., Caccialanza, R. and Pezzoli, G. (2013) Diabetes and Risk of Parkinson's Disease. Movement Disorders, 28, 257-261. http://dx.doi.org/10.1002/mds.25211

[33] Vikdahl, M., Carlsson, M., Linder, J., Forsgren, L. and Håglin, L. (2014) Weight Gain and Increased Central Obesity in the Early Phase of Parkinson's Disease. Clinical Nutrition, 33, 1132-1139. http://dx.doi.org/10.1016/j.clnu.2013.12.012

[34] Bousquet, M., St-Amour, I., Vandal, M., Julien, P., Cicchetti, F. and Calon, F. (2012) High-Fat Diet Exacerbates MPTP-Induced Dopaminergic Degeneration in Mice. Neurobiology of Disease, 45, 529-538. http://dx.doi.org/10.1016/j.nbd.2011.09.009

[35] Mattson, M.P. (2014) Interventions That Improve Body and Brain Bioenergetics for Parkinson's Disease Risk Reduction and Therapy. Journal of Parkinson's Disease, 4, 1-13.

[36] Lovatel, G.A., Elsner, V.R., Bertoldi, K., Vanzella, C., dos Santos Moyses, F., Vizuete, A., Spindler, C., Reck Cechinel, L., Netto, C.A., Muotri, A.R. and Rodrigues Siqueira, I. (2013) Treadmill Exercise Induces Age-Related Changes in Aversive Memory, Neuroinflammatory and Epigenetic Processes in the Rat Hippocampus. Neurobiology of Learning and Memory, 101, 94-102. http://dx.doi.org/10.1016/j.nlm.2013.01.007

[37] Zhang, F.F., Cardarelli, R., Carroll, J., Zhang, S., Fulda, K.G., Gonzalez, K., Vishwanatha, J.K., Morabia, A. and Santella, R.M. (2011) Physical Activity and Global Genomic DNA Methylation in a Cancer-Free Population. Epigenetics, 6, 293-299. http://dx.doi.org/10.4161/epi.6.3.14378

[38] Thomas, J.L. (2013) Helpful or Harmful? Potential Effects of Exercise on Select Inflammatory Conditions. Physician and Sports Medicine, 41, 93-100. http://dx.doi.org/10.3810/psm.2013.11.2040

[39] Ling, C. and Rönn, T. (2014) Epigenetic Adaptation to Regular Exercise in Humans. Drug Discovery Today, 19, 10151018.

[40] Sciolino, N.R. and Holmes, P.V. (2012) Exercise Offers Anxiolytic Potential: A Role for Stress and Brain Noradrenergic-Galaninergic Mechanisms. Neuroscience \& Biobehavioral Reviews, 36, 1965-1984. http://dx.doi.org/10.1016/j.neubiorev.2012.06.005

[41] Szalai, Z., Szász, A., Nagy, I., Puskás, L.G., Kupai, K., Király, A., Berkó, A.M., Pósa, A., Strifler, G., Baráth, Z., Nagy, L.I., Szabó, R., Pávó, I., Murlasits, Z., Gyöngyösi, M. and Varga, C. (2014) Anti-Inflammatory Effect of Recreational Exercise in TNBS-Induced Colitis in Rats: role of NOS/HO/MPO System. Oxidative Medicine and Cellular Longevity, 2014, Article ID: 925981. http://dx.doi.org/10.1155/2014/925981

[42] Archer, T. (2014) Health Benefits of Physical Exercise for Children and Adolescents. Journal of Novel Physiotherapies, 4, 203. http://dx.doi.org/10.4172/2165-7025.1000203

[43] Das, J., Roy, A. and Sil, P.C. (2012) Mechanism of the Protective Action of Taurine in Toxin and Drug Induced Organ Pathophysiology and Diabetic Complications: A Review. Food \& Function, 3, 1251-1264.

http://dx.doi.org/10.1039/c2fo30117b 
[44] Huang, X., Wang, F., Chen, W., Chen, Y., Wang, N. and von Maltzan, K. (2012) Possible Link between the Cognitive Dysfunction Associated with Diabetes Mellitus and the Neurotoxicity of Methylglyoxal. Brain Research, 1469, 82-91. http://dx.doi.org/10.1016/j.brainres.2012.06.011

[45] Lirk, P., Flatz, M., Haller, I., Hausott, B., Blumenthal, S., Stevens, M.F., Suzuki, S., Klimaschewski, L. and Gerner, P. (2012) In Zucker Diabetic Fatty Rats, Subclinical Diabetic Neuropathy Increases in Vivo Lidocaine Block Duration but Not in Vitro Neurotoxicity. Regional Anesthesia \& Pain Medicine, 37, 601-606. http://dx.doi.org/10.1097/AAP.0b013e3182664afb

[46] Loprinzi, P.D., Cardinal, B.J., Loprinzi, K.L. and Lee. H. (2012) Benefits and Environmental Determinants of Physical Activity in Children and Adolescents. Obesity Facts, 5, 597-610. http://dx.doi.org/10.1159/000342684

[47] Lukacs, A., Mayer, K., Juhasz, E., Varga, B., Foder, B. and Barkai, L. (2012) Reduced Physical Fitness in Children and Adolescents with Type 1 Diabetes. Pediatric Diabetes, 13, 432-437. http://dx.doi.org/10.1111/j.1399-5448.2012.00848.x

[48] Maggio, A.B.R., Hofer, M.F., Martin, X.E., Marchand, L.M., Beghetti, M. and Farpour-Lambert, N.J. (2010) Reduced Physical Activity Level and Cardiorespiratory Fitness in Children with Chronic Diseases. European Journal of Pediatrics, 169, 1187-1193. http://dx.doi.org/10.1007/s00431-010-1199-2

[49] Brazeau, A.S., Rabasa-Lloret, R., Strychar, I. and Mircescu, H. (2008) Barriers to Physical Activity among Patients with Type 1 Diabetes. Diabetes Care, 31, 2108-2109. http://dx.doi.org/10.2337/dc08-0720

[50] Sherr, J.L., Cengiz, E., Palerm, C.C., Clark, B., Kurtz, N., Roy, A., Carria, L., Cantwell, M., Tamborlane, W.V. and Weinzimer, S.A. (2013) Reduced Hypoglycemia and Increased Time in Target Using Closed-Loop Insulin Delivery during Nights with or without Antecedent Afternoon Exercise in Type 1 Diabetes. Diabetes Care, 36, 2909-2914. http://dx.doi.org/10.2337/dc13-0010

[51] Chimen, M., Kennedy, A., Nirantharakumar, K., Pang, T.T., Andrews, R. and Narendran, P. (2012) What Are Health Benefits of Physical Activity in Type 1 Diabetes Mellitus? A Literature Review. Diabetologia, 55, 542-551. http://dx.doi.org/10.1007/s00125-011-2403-2

[52] Cuenca-Garcia, M., Jago, R., Shield, J.P. and Burren, C.P. (2012) How Does Physical Activity and Fitness Influence Glycaemic Control in Young People with Type 1 Diabetes? Diabetic Medicine, 29, e369-e376. http://dx.doi.org/10.1111/j.1464-5491.2012.03740.x

[53] Singhvi, A., Tansey, M.J., Janz, K., Zimmerman, M.B. and Tsalikian, E. (2014) Aerobic Fitness and Glycemic Variability in Adolescents with Type 1 Diabetes. Endocrine Practice, 20, 566-570.

[54] Metcalf, K.M., Singhvi, A., Tsalikian, E., Tansey, M.J., Zimmerman, M.B., Esliger, D.W. and Janz, K.F. (2014) Effects of Moderate-to-Vigorous Intensity Physical Activity on Overnight and Next-Day Hypoglycemia in Active Adolescents with Type 1 Diabetes. Diabetes Care, 37, 1272-1278. http://dx.doi.org/10.2337/dc13-1973

[55] Davey, R.J., Howe, W., Paramalingam, N., Ferreira, L.D., Davis, E.A., Fournier, P.A. and Jones, T.W. (2013) The Effect of Midday Moderate-Intensity Exercise on Postexercise Hypoglycemia Risk in Individuals with Type 1 Diabetes. The Journal of Clinical Endocrinology and Metabolism, 98, 2908-2914. http://dx.doi.org/10.1210/jc.2013-1169

[56] Galassetti, P. and Riddell, M.C. (2013) Exercise and Type 1 Diabetes (T1DM). Comprehensive Physiology, 3, 13091336.

[57] Ackermann, P.W. and Hart, D.A. (2013) Influence of Comorbidities: Neuropathy, Vasculopathy, and Diabetes on Healing Response Quality. Advances in Wound Care, 2, 410-421. http://dx.doi.org/10.1089/wound.2012.0437

[58] O’Brien, P.D., Sakowski, S.A. and Feldman, E.L. (2014) Mouse Models of Diabetic Neuropathy. ILAR Journal, 54, 259-272. http://dx.doi.org/10.1093/ilar/ilt052

[59] Vinik, A.I. and Erbas, T. (2013) Diabetic Autonomic Neuropathy. Handbook of Clinical Neurology, 117, $279-294$. http://dx.doi.org/10.1016/B978-0-444-53491-0.00022-5

[60] Guo, S.S., Wu, W., Chumlea, W.C. and Roche, A.F. (2002) Predicting Overweight and Obesity in Adulthood from Body Mass Index Values in Childhood and Adolescence. American Journal of Clinical Nutrition, 76, 653-658.

[61] Shin, K.O., Moritani, T., Woo, J., Jang, K.S., Bae, J.Y., Yoo, J. and Kang, S. (2014) Exercise Training Improves Cardiac Autonomic Nervous System Activity in Type 1 Diabetic Children. Journal of Physical Therapy Science, 26, 111115. http://dx.doi.org/10.1589/jpts.26.111

[62] Wawryk, A.M., Bates, D.J. and Couper, J.J. (1997) Power Spectral Analysis of Heart Rate Variability in Children and Adolescents with IDDM. Diabetes Care, 20, 1416-1421. http://dx.doi.org/10.2337/diacare.20.9.1416

[63] Zeigler, D. (1994) Diabetic Cardiovascular Autonomic Neuropathy: Prognosis, Diagnosis and Treatment. Diabetes/ Metabolism Reviews, 10, 339-383. http://dx.doi.org/10.1002/dmr.5610100403

[64] Zoeger, D., Gries, F.A., Mühlen, H., Rathmann, W., Spüler, M. and Lessmann, F. (1993) Prevalence and Clinical Correlates of Cardiovascular Autonomic and Peripheral Diabetic Neuropathy in Patients Attending Diabetic Centers. Diabetes \& Metabolism, 19, 143-151. 
[65] Herbst, A., Kordonouri, O., Schwab, K.O., Schmidt, F., Holl, R.W., DPV Initiative of the German Working Group for Pediatric Diabetology Germany (2007) Impact of Physical Activity on Cardiovascular Risk Factors in Children with Type 1 Diabetes. Diabetes Care, 30, 2098-2100. http://dx.doi.org/10.2337/dc06-2636

[66] Leggio, M., Mazza, A., Cruciani, G., Sgorbini, L., Pugliese, M., Bendini, M.G., Severi, P. and Jesi, A.P. (2014) Effects of Exercise Training on Systo-Diastolic Ventricular Dysfunction in Patients with Hypertension: An Echocardiographic Study with Tissue Velocity and Strain Imaging Evaluation. Hypertension Research, 37, 649-654. http://dx.doi.org/10.1038/hr.2014.44

[67] Gianini, L.M., White, M.A. and Masheb, R.M. (2013) Eating Pathology, Emotion Regulation, and Emotional Overeating in Obese Adults with Binge Eating Disorder. Eating Behaviors, 14, 309-313. http://dx.doi.org/10.1016/j.eatbeh.2013.05.008

[68] Bongers, P., Jansen, A., Havermans, R., Roefs, A. and Nederkoorn, C. (2013) Happy Eating: The Underestimated Role of Overeating in a Positive Mood. Appetite, 67, 74-80. http://dx.doi.org/10.1016/j.appet.2013.03.017

[69] Brownstone, L.M., Bardone-Cone, A.M., Fitzsimmons-Craft, E.E., Printz, K.S., Le Grange, D., Mitchell, J.E., Crow, S.J., Peterson, C.B., Crosby, R.D., Klein, M.H., Wonderlich, S.A. and Joiner, T.E. (2013) Subjective and Objective Binge Eating in Relation to Eating Disorder Symptomatology, Negative Affect, and Personality Dimensions. International Journal of Eating Disorders, 46, 66-76. http://dx.doi.org/10.1002/eat.22066

[70] Foran, E., Hannigan, A. and Glynn, L. (2014) Prevalence of Depression in Patients with Type 2 Diabetes Mellitus in Irish Primary Care and the Impact of Depression on the Control of Diabetes. Irish Journal of Medical Sciences. (Epub Ahead of Print)

[71] Roberts, R.O., Knopman, D.S., Przybelski, S.A., Mielke, M.M., Kantarci, K., Preboske, G.M., Senjem, M.L., Pankratz, V.S., Geda, Y.E., Boeve, B.F., Ivnik, R.J., Rocca, W.A., Petersen, R.C. and Jack, C.R. (2014) Association of Type 2 Diabetes with Brain Atrophy and Cognitive Impairment. Neurology, 82, 1132-1141. http://dx.doi.org/10.1212/WNL.0000000000000269

[72] Berg, K.C., Peterson, C.B., Crosby, R.D., Cao, L., Crow, S.J., Engel, S.G. and Wonderlich, S.A. (2014) Relationship between Daily Affect and Overeating-Only, Loss of Control Eating-Only, and Binge Eating Episodes in Obese Adults. Psychiatry Research, 215, 185-191. http://dx.doi.org/10.1016/j.psychres.2013.08.023

[73] Danner, U.N., Evers, C., Sternheim, L., van Meer, F., van Elburg, A.A., Geerets, T.A., Breteler, L.M. and de Ridder, D.T. (2013) Influence of Negative Affect on Choice Behavior in Individuals with Binge Eating Pathology. Psychiatry Research, 207, 100-106. http://dx.doi.org/10.1016/j.psychres.2012.10.016

[74] Kekic, M., McClelland, J., Campbell, I., Nestler, S., Rubia, K., David, A.S. and Schmidt, U. (2014) The Effects of Prefrontal Cortex Transcranial Direct Current Stimulation (tDCS) on Food Craving and Temporal Discounting in Women with Frequent Food Cravings. Appetite, 78, 55-62. http://dx.doi.org/10.1016/j.appet.2014.03.010

[75] Willeumier, K.C., Taylor, D.V. and Amen, D.G. (2011) Elevated BMI Is Associated with Decreased Blood Flow in the Prefrontal Cortex Using SPECT Imaging in Healthy Adults. Obesity, 19, 1095-1097. http://dx.doi.org/10.1038/oby.2011.16

[76] Gibson, E.L. (2012) The Psychobiology of Comfort Eating: Implications for Neuropharmacological Interventions. Behavioural Pharmacology, 23, 442-460. http://dx.doi.org/10.1097/FBP.0b013e328357bd4e

[77] Heidor, B. and Welch, M. (2010) Teaching Affective Qualities in Physical Education. Strategies: A Journal for Physical and Sport Educators, 23, 16-21.

[78] Lunn, T.E., Nowson, C.A., Worsley, A. and Torres, S.J. (2014) Does Personality Affect Dietary Intake? Nutrition, 30, 403-409. http://dx.doi.org/10.1016/j.nut.2013.08.012

[79] Murphy, C.M., Stojek, M.K. and Mackillop, J. (2013) Interrelationships among Impulsive Personality Traits, Food Addiction, and Body Mass Index. Appetite, 73, 45-50.

[80] Baños, R.M., Cebolla, A., Moragrega, I., Van Strien, T., Fernández-Aranda, F., Agüera, Z., de la Torre, R., Casanueva, F.F., Fernández-Real, J.M., Fernández-García, J.C., Frühbeck, G., Gómez-Ambrosi, J., Jiménez-Murcia, S., Rodríguez, R., Tinahones, F.J. and Botella, C. (2014) Relationship between Eating Styles and Temperament in an Anorexia Nervosa, Healthy Control, and Morbid Obesity Female Sample. Appetite, 76, 76-83. http://dx.doi.org/10.1016/j.appet.2014.01.012

[81] Archer, T. and Fredriksson, A. (2013) The Yeast Product Milmed Enhances the Effect of Physical Exercise on Motor Performance and Dopamine Neurochemistry Recovery in MPTP-Lesioned Mice. Neurotoxicity Research, 24, 393-406. http://dx.doi.org/10.1007/s12640-013-9405-4

[82] Souza, L.C., Filho, C.B., Goes, A.T., Fabbro, L.D., de Gomes, M.G., Savegnago, L., Oliveira, M.S. and Jesse, C.R. (2013) Neuroprotective Effect of Physical Exercise in a Mouse Model of Alzheimer's Disease Induced by $\beta$-Amyloid I-40 Peptide. Neurotoxicity Research, 24, 148-163. http://dx.doi.org/10.1007/s12640-012-9373-0

[83] Huang, T.Y., Lin, L.S., Cho, K.C., Chen, S.J., Kuo, Y.M., Yu, L., Wu, F.S., Chuang, J.I., Chen, H.I. and Jen. C.J. 
(2012) Chronic Treadmill Exercise in Rats Delicately Alters the Purkinje Cell Structure to Improve Motor Performance and Toxin Resistance in the Cerebellum. Journal of Applied Physiology, 113, 889-895.

[84] Aguiar Jr., A.S., Tristão, F.S., Amar, M., Chevarin, C., Glaser, V., de Paula Martins, R., Moreira, E.L., Mongeau, R., Lanfumey, L., Raisman-Vozari, R., Latini, A. and Prediger, R.D. (2014) Six Weeks of Voluntary Exercise Don’t Protect C57BL/6 Mice against Neurotoxicity of MPTP and MPP ${ }^{+}$. Neurotoxicity Research, 25, 147-152. http://dx.doi.org/10.1007/s12640-013-9412-5

[85] Gerecke, K.M., Jiao, Y., Pagala, V. and Smeyne, R.J. (2012) Exercise Does Not Protect against MPTP-Induced Neurotoxicity in BDNF Haploinsufficient Mice. PLoS One, 7, e43250. http://dx.doi.org/10.1371/journal.pone.0043250

[86] Hosseinzad, S., Dabidi Roshan, V. and Pourasghar, M. (2013) Effects of Intermittent Aerobic Training on Passive Avoidance Test (Shuttle Box) and Stress Markers in the Dorsal Hippocampus of Wistar Rats Exposed to Administration of Homocysteine. Iranian Journal of Psychiatry and Behavioral Sciences, 7, 37-44.

[87] Wang, Q., Xu, Z., Tang, J., Sun, J., Gao, J., Wu, T. and Xiao, M. (2013) Voluntary Exercise Counteracts A $\beta 25-35-I n-$ duced Memory Impairment in Mice. Behavioural Brain Research, 256, 618-625. http://dx.doi.org/10.1016/j.bbr.2013.09.024

[88] Aguiar Jr., A.S., Moreira, E.L., Hoeller, A.A., Oliveira, P.A., Córdova, F.M., Glaser, V., Walz, R., Cunha, R.A., Leal, R.B., Latini, A. and Prediger, R.D. (2013) Exercise Attenuates Levodopa-Induced Dyskinesia in 6-HydroxydopamineLesioned Mice. Neuroscience, 243, 46-53. http://dx.doi.org/10.1016/j.neuroscience.2013.03.039

[89] Funk, J.A., Gohlke, J., Kraft, A.D., McPherson, C.A., Collins, J.B. and Jean Harry, G. (2011) Voluntary Exercise Protects Hippocampal Neurons from Trimethyltin Injury: Possible Role of Interleukin-6 to Modulate Tumor Necrosis Factor Receptor-Mediated Neurotoxicity. Brain, Behavior, and Immunity, 25, 1063-1077. http://dx.doi.org/10.1016/j.bbi.2011.03.012

[90] Hayashino, Y., Jackson, J.L., Hirata, T., Fukumori, N., Nakamura, F., Fukuhara, S., Tsujii, S. and Ishii, H. (2014) Effects of Exercise on C-Reactive Protein, Inflammatory Cytokine and Adipokine in Patients with Type 2 Diabetes: A Meta-Analysis of Randomized Controlled Trials. Metabolism, 63, 431-440. http://dx.doi.org/10.1016/j.metabol.2013.08.018

[91] Foulds, H.J., Bredin, S.S., Charlesworth, S.A., Ivey, A.C. and Warburton, D.E. (2014) Exercise Volume and Intensity: A Dose-Response Relationship with Health Benefits. European Journal of Applied Physiology, 114, 1563-1571.

[92] Nicolucci, A., Balducci, S., Cardelli, P., Cavallo, S., Fallucca, S., Bazuro, A., Simonelli, P., Iacobini, C., Zanuso, S. and Pugliese, G., for the Italian Diabetes Exercise Study (IDES) Investigators (2012) Relationship of Exercise Volume to Improvements of Quality of Life with Supervised Exercise Training in Patients with Type 2 Diabetes in a Randomised Controlled Trial: The Italian Diabetes and Exercise Study (IDES). Diabetologia, 55, 579-588. http://dx.doi.org/10.1007/s00125-011-2425-9

[93] Stampfer, M., Hu, F., Manson, J., Rimm, E. and Willett, W. (2000) Primary Prevention of Coronary Heart Disease in Women through Diet and Lifestyle. The New England Journal of Medicine, 343, 16-23. http://dx.doi.org/10.1056/NEJM200007063430103

[94] Mougios, V. (2010) Exercise Metabolism. In: Bahrke, M.S, Ed., Exercise Biochemistry, Human Kinetics, Champaign, $122 \mathrm{p}$.

[95] Ormsbee, M.J., Choi, M.D., Medlin, J.K., Geyer, G.H., Trantham, L.H., Dubis, G.S. and Hicknerm R.C. (2009) Regulation of Fat Metabolism during Resistance Exercise in Sedentary Lean and Obese Men. Journal of Applied Physiology, 106, 1529-1537. http://dx.doi.org/10.1152/japplphysiol.91485.2008

[96] Archer, T. (2011) Physical Exercise Alleviates Debilities of Normal Aging and Alzheimer's Disease. Acta Neurologica Scandinavica, 123, 221-238. http://dx.doi.org/10.1111/j.1600-0404.2010.01412.x

[97] Archer, T. (2013) Influence of Physical Exercise on Traumatic Brain Injury Deficits: Scaffolding Effect. Neurotoxicity Research, 21, 418-434. http://dx.doi.org/10.1007/s12640-011-9297-0

[98] Archer, T. and Fredriksson, A. (2010) Physical Exercise Attenuates MPTP Induced Deficits in Mice. Neurotoxicity Research, 18, 313-327. http://dx.doi.org/10.1007/s12640-010-9168-0

[99] Archer, T., Fredriksson, A., Schütz, E. and Kostrzewa, R.M. (2011) Influence of Physical Exercise on Neuroimmunological Functioning and Health: Aging and Stress. Neurotoxicity Research, 20, 69-83. http://dx.doi.org/10.1007/s12640-010-9224-9

[100] Archer, T., Svensson, K. and Alricsson, M. (2012) Physical Exercise Ameliorates Deficits Induced by Traumatic Brain Injury. Acta Neurologica Scandinavica, 125, 293-302. http://dx.doi.org/10.1111/j.1600-0404.2011.01638.x

[101] Fredriksson, A., Stigsdotter, I.M., Hurtig, A., Ewalds-Kvist, B. and Archer, T. (2011) Running Wheel Activity Restores MPTP-Induced Deficits. Journal of Neural Transmission, 118, 407-420. http://dx.doi.org/10.1007/s00702-010-0474-8

[102] Ang, E.T., Wong, P.T., Moochhala, S. and Ng, Y.K. (2003) Neuroprotection Associated with Running: Is It a Result of 
Increased Endogenous Neurotrophic Factors? Neuroscience, 118, 335-345. http://dx.doi.org/10.1016/S0306-4522(02)00989-2

[103] Ang, E.T. and Gomez-Pinilla, F. (2007) Potential Therapeutic Effects of Exercise to the Brain. Current Medicinal Chemistry, 14, 2564-2571. http://dx.doi.org/10.2174/092986707782023280

[104] Garcia, D., Archer, T., Moradi, S. and Andersson-Arntén, A-C. (2012) Exercise Frequency, High Activation Positive Affectivity, and Psychological Well-Being: Beyond Age, Gender, and Occupation. Psychology, 3, 328-336. http://dx.doi.org/10.4236/psych.2012.34047

[105] Palomo, T., Beninger, R.J., Kostrzewa, R.M. and Archer, T. (2008) Affective Status in Relation to Impulsiveness, Motor and Motivational Symptoms: Personality, Development and Physical Exercise. Neurotoxicity Research, 14, 151168. http://dx.doi.org/10.1007/BF03033807

[106] Fontana, L. and Hu, F.B. (2014) Optimal Body Weight for Health and Longevity: Bridging Basic, Clinical, and Population Research. Aging Cell, 13, 371-400. http://dx.doi.org/10.1111/acel.12207

[107] Ikeda, S., Tamura, Y., Kakehi, S., Takeno, K., Kawaguchi, M., Watanabe, T., Sato, F., Ogihara, T., Kanazawa, A., Fujitani, Y., Kawamori, R. and Watada, H. (2013) Exercise-Induced Enhancement of Insulin Sensitivity Is Associated with Accumulation of M2-Polarized Macrophages in Mouse Skeletal Muscle. Biochemical and Biophysical Research Communications, 441, 36-41. http://dx.doi.org/10.1016/j.bbrc.2013.10.005

[108] Fedewa, M.V., Gist, N.H., Evans, E.M. and Dishman, R.K. (2014) Exercise and Insulin Resistance in Youth: A MetaAnalysis. Pediatrics, 133, e163-e174. http://dx.doi.org/10.1542/peds.2013-2718

[109] Loi, S.M., Dow, B., Ames, D., Moore, K., Hill, K., Russell, M. and Lautenschlager, N. (2014) Physical Activity in Caregivers: What Are the Psychological Benefits? Archives of Gerontology and Geriatrics, 59, 204-210. http://dx.doi.org/10.1016/j.archger.2014.04.001

[110] Napoli, N., Shah, K., Waters, D.L., Sinacore, D.R., Qualls, C. and Villareal, D.T. (2014) Effect of Weight Loss, Exercise, or Both on Cognition and Quality of Life in Obese Older Adults. American Journal of Clinical Nutrition, 100, 189-198.

[111] Nelson, R.K. and Horowitz, J.F. (2014) Acute Exercise Ameliorates Differences in Insulin Resistance between Physically Active and Sedentary Overweight Adults. Applied Physiology Nutrition and Metabolism-Physiologie, 39, 811818.

[112] Legrand, D., Vaes, B., Matheï, C., Adriaensen, W., Van Pottelbergh, G. and Degryse, J.M. (2014) Muscle Strength and Physical Performance as Predictors of Mortality, Hospitalization, and Disability in the Oldest Old. Journal of the American Geriatrics Society, 62, 1030-1038. http://dx.doi.org/10.1111/jgs.12840

[113] Moore, A.Z., Caturegli, G., Metter, E.J., Makrogiannis, S., Resnick, S.M., Harris, T.B. and Ferrucci, L. (2014) Difference in Muscle Quality over the Adult Life Span and Biological Correlates in the Baltimore Longitudinal Study of Aging. Journal of the American Geriatrics Society, 62, 230-236. http://dx.doi.org/10.1111/jgs.12653

[114] Porter Starr, K.N., McDonald, S.R. and Bales, C.W. (2014) Obesity and Physical Frailty in Older Adults: A Scoping Review of Lifestyle Intervention Trials. Journal of Post-Acute and Long Term Care Medicine, 15, 240-250. http://dx.doi.org/10.1016/j.jamda.2013.11.008

[115] Mavros, Y., Kay, S., Simpson, K.A., Baker, M.K., Wang, Y., Zhao, R.R., Meiklejohn, J., Climstein, M., O’Sullivan, A.J., de Vos, N., Baune, B.T., Blair, S.N., Simar, D., Rooney, K., Singh, N.A. and Fiatarone Singh, M.A. (2014) Reductions in C-Reactive Protein in Older Adults with Type 2 Diabetes Are Related to Improvements in Body Composition Following a Randomized Controlled Trial of Resistance Training. Journal of Cachexia, Sarcopenia and Muscle, 5, 111-120.

[116] Levine, B. and Kroemer, G. (2008) Autophagy in the Pathogenesis of Disease. Cell, 132, 27-42. http://dx.doi.org/10.1016/j.cell.2007.12.018

[117] Mizushima, N., Levine, B., Cuervo, A.M. and Klionsky, D.J. (2008) Autophagy Fights Disease through Cellular SelfDigestion. Nature, 451, 1069-1075. http://dx.doi.org/10.1038/nature06639

[118] Esclatine, A., Chaumorcel, M. and Codogna, P. (2009) Macroautophagy Signaling and Regulation. In: Levine, B., Yoshimori, T. and Deretic, V., Eds., Autophagy in Infection and Immunity, Current Topics in Microbiology and Immunology, Springer-Verlag, Berlin, 33-70. http://dx.doi.org/10.1007/978-3-642-00302-8_2

[119] Deretic, V. and Tooze, S.A. (2012) Autophagy in Stress, Development and Disease. Gordon Research Seminar, Ventura.

[120] Archer, T. and Kostrzewa, R.M. (2013) The Inductive Agency of Stress: From Perinatal to Adolescent Induction. In: Laviola, G., and Macri, S., Eds., Adaptive and Maladaptive Aspects of Developmental Stress, Current Topics in Neurotoxicity, Springer Science+Business, New York, 1-20.

[121] He, C., Sumpter, R. and Levine, B. (2012) Exercise Induces Autophagy in Peripheral Tissues and in the Brain. Autophagy, 8, 1548-1551. http://dx.doi.org/10.4161/auto.21327 
[122] Ferraro, E., Giammarioli, A.M., Chiandotto, S., Spoletini, I. and Rosano, G. (2014) Exercise-Induced Skeletal Muscle Remodeling and Metabolic Adaptation: Redox Signaling and Role of Autophagy. Antioxidants \& Redox Signaling, 21, 154-176.

[123] Tam, B.T. and Siu, P.M. (2014) Autophagic Cellular Responses to Physical Exercise in Skeletal Muscle. Sports Medicine, 44, 625-640. http://dx.doi.org/10.1007/s40279-013-0140-z

[124] Zampieri, S., Pietrangelo, L., Loefler, S., Fruhmann, H., Vogelauer, M., Burggraf, S., Pond, A., Grim-Stieger, M., Cvecka, J., Sedliak, M., Tirpáková, V., Mayr, W., Sarabon, N., Rossini, K., Barberi, L., De Rossi, M., Romanello, V., Boncompagni, S., Musarò, A., Sandri, M., Protasi, F., Carraro, U. and Kern, H. (2014) Lifelong Physical Exercise Delays Age-Associated Skeletal Muscle Decline. Journals of Gerontology Series A-Biological Sciences and Medical Sciences.

[125] Bayod, S., Del Valle, J., Pelegri, C., Vilaplana, J., Canudas, A.M., Camins, A., Jimenez, A., Sanchez-Roige, S., Lalanza, J.F., Escorihuela, R.M. and Pallas. M. (2014) Macroautophagic Process Was Differentially Modulated by LongTerm Moderate Exercise in Rat Brain and Peripheral Tissues. Journal of Physiology and Pharmacology, 65, $229-239$.

[126] Yan, Z., Lira, V.A. and Greene, N.P. (2012) Exercise Training-Induced Regulation of Mitochondrial Quality. Exercise and Sport Sciences Reviews, 40, 159-164.

[127] Sarzi, E., Angebault, C., Seveno, M., Gueguen, N., Chaix, B., Bielicki, G., Boddaert, N., Mausset-Bonnefont, A.L., Cazevieille, C., Rigau, V., Renou, J.P., Wang, J., Delettre, C., Brabet, P., Puel, J.L., Hamel, C.P., Reynier, P. and Lenaers, G. (2012) The Human OPA1 $1^{\text {delTTAG }}$ Mutation Induces Premature Age-Related Systemic Neurodegeneration in Mouse. Brain, 135, 3599-3613. http://dx.doi.org/10.1093/brain/aws303

[128] Moro-García, M.A., Fernández-García, B., Echeverría, A., Rodríguez-Alonso, M., Suárez-García, F.M., Solano-Jaurrieta, J.J., López-Larrea, C. and Alonso-Arias, R. (2013) Frequent Participation in High Volume Exercise Throughout Life Is Associated with a More Differentiated Adaptive Immune Response. Brain, Behavior, and Immunity, 39, 61-74.

[129] Voss, M.W., Prakash, R.S., Erickson, K.I., Basak, C., Chaddock, L., Kim, J.S., Alves, H., Heo, S., Szabo, A.N., White, S.M., Wojcicki, T.R., Mailey, E.L., Gothe, N., Olson, E.A., McAuley, E. and Kramer, A.F. (2010) Plasticity of Brain Networks in a Randomized Intervention Trial of Exercise Training in Older Adults. Frontiers in Aging Neuroscience, 2 , pii: 32.

[130] He, S.B., Tang, W.G., Tang, W.J., Kao, X.L., Zhang, C.G. and Wong, X.T. (2012) Exercise Intervention May Prevent Depression. International Journal of Sports Medicine, 33, 525-530. http://dx.doi.org/10.1055/s-0032-1306325

[131] Burdette, J.H., Laurienti, P.J., Espeland, M.A., Morgan, A., Telesford, Q., Vechlekar, C.D., Hayasaka, S., Jennings, J.M., Katula, J.A., Kraft, R.A. and Rajeski, W.J. (2010) Using Network Science to Evaluate Exercise-Associated Brain Changes in Older Adults. Frontiers in Aging Neuroscience, 2.

[132] Cotman, C.W., Berchtold, N.C. and Christie, L.A. (2007) Exercise Builds Brain Health: Key Roles of Growth Factor Cascades and Inflammation. Trends in Neurosciences, 30, 464-472. http://dx.doi.org/10.1016/j.tins.2007.06.011

[133] Llorens-Martin, M., Torres-Alaman, I. and Trejo, J.L. (2008) Growth Factors as Mediators of Exercise Actions on the Brain. NeuroMolecular Medicine, 10, 99-107. http://dx.doi.org/10.1007/s12017-008-8026-1

[134] Mattson, M.P. (2008) Glutamate and Neurotrophic Factors in Neuronal Plasticity and Disease. Annals of the New York Academy of Sciences, 1144, 97-112. http://dx.doi.org/10.1196/annals.1418.005

[135] Kishi, T. and Sunagawa, K. (2013) Exercise Training Plus Calorie Restriction Causes Synergistic Protection against Cognitive Decline via Up-Regulation of BDNF in Hippocampus of Stroke-Prone Hypertensive Rats. Proceedings of IEEE Engineering in Medicine and Biology Society, 2012, 6764-6767.

[136] Khabour, O.F., Alzoubi, K.H., Alomari, M.A. and Alzubi, M.A. (2010) Changes in Spatial Memory and BDNF Expression to Concurrent Dietary Restriction and Voluntary Exercise. Hippocampus, 20, 637-645.

[137] Khabour, O.F., Alzoubi, K.H., Alomari, M.A. and Alzubi, M.A. (2013) Changes in Spatial Memory and BDNF Expression to Simultaneous Dietary Restriction and Forced Exercise. Brain Research Bulletin, 90, 19-24. http://dx.doi.org/10.1016/j.brainresbull.2012.08.005

[138] Knikou, M. (2012) Plasticity of Corticospinal Neural Control after Locomotor Training in Human Spinal Cord Injury. Neural Plasticity, 2012, Article ID: 254948. http://dx.doi.org/10.1155/2012/254948

[139] Bean, M.K., Powell, P., Quinoy, A., Ingersoll, K., Wickham III., E.P. and Mazzeo, S.E. (2014) Motivational Interviewing Targeting Diet and Physical Activity Improves Adherence to Paediatric Obesity Treatment: Results from the MI Values Randomized Controlled Trial. Pediatric Obesity, Early View (Online Version of Record published before inclusion in an issue). http://dx.doi.org/10.1111/j.2047-6310.2014.226.x

[140] Kouvelioti, R., Vagenas, G. and Langley-Evans, S. (2014) Effects of Exercise and Diet on Weight Loss Maintenance in Overweight and Obese Adults: A Systematic Review. The Journal of Sports Medicine and Physical Fitness, 54, 456-474.

[141] Miller, P.E., Alexander, D.D. and Perez, V. (2014) Effects of Whey Protein and Resistance Exercise on Body Compo- 
sition: a Meta-Analysis of Randomized Controlled Trials. Journal of the American College of Nutrition, 33, 163-175. http://dx.doi.org/10.1080/07315724.2013.875365

[142] Simpson, R.J. and Bosch, J.A. (2014) Special Issue on Exercise Immunology: Current Perspectives on Aging, Health and Extreme Performance. Brain, Behavior, and Immunity, 39, 1-7.

[143] Sylvia, L.G., Salcedo, S., Bernstein, E.E., Baek, J.H., Nierenberg, A.A. and Deckersbach, T. (2014) Nutrition, Exercise, and Wellness Treatment in Bipolar Disorder: Proof of Concept for a Consolidated Intervention. International Journal of Bipolar Disorders, 1, 24.

[144] García-Calzón, S., Moleres, A., Marcos, A., Campoy, C., Moreno, L.A., Azcona-Sanjulián, M.C., Martínez-González, M.A., Martínez, J.A., Zalba, G. and Marti, A., EVASYON Study Group (2014) Telomere Length as a Biomarker for Adiposity Changes after a Multidisciplinary Intervention in Overweight/Obese Adolescents: The EVASYON Study. PLoS One, 9, e89828. http://dx.doi.org/10.1371/journal.pone.0089828

[145] Swift, D.L., Johannsen, N.M., Lavie, C.J., Earnest, C.P. and Church, T.S. (2014) The Role of Exercise and Physical Activity in Weight Loss and Maintenance. Progress in Cardiovascular Diseases, 56, 441-447. http://dx.doi.org/10.1016/j.pcad.2013.09.012

[146] Moholdt, T., Wisløff, U., Lydersen, S. and Nauman, J. (2014) Current Physical Activity Guidelines for Health Are Insufficient to Mitigate Long-Term Weight Gain: More Data in the Fitness versus Fatness Debate (The HUNT Study, Norway). British Journal of Sports Medicine, 48, 1489-1496.http://dx.doi.org/10.1136/bjsports-2014-093416

[147] Kowalska, I., Borawski, J., Nikołajuk, A., Budlewski, T., Otziomek, E., Górska, M. and Strączkowski, M. (2011) Insulin Sensitivity, Plasma Adiponectin and sICAM- ${ }_{-1}$ Concentrations in Patients with Subclinical Hypothyroidism: Response to Levothyroxine Therapy. Endocrine, 40, 95-101. http://dx.doi.org/10.1007/s12020-011-9446-5

[148] Polin, R.S., Bavbek, M., Shaffrey, M.E., Billups, K., Bogaev, C.A., Kassell, N.F. and Lee, K.S. (1998) Detection of Soluble E-Selectin, ICAM-1, VCAM-1, and L-Selectin in the Cerebrospinal Fluid of Patients after Subarachnoid Hemorrhage. Journal of Neurosurgery, 89, 559-567. http://dx.doi.org/10.3171/jns.1998.89.4.0559

[149] Ryan, A.S., Ge, S., Blumenthal, J.B., Serra, M.C., Prior, S.J. and Goldberg, A.P. (2014) Aerobic Exercise and Weight Loss Reduce Vascular Markers of Inflammation and Improve Insulin Sensitivity in Obese Women. Journal of the American Geriatrics Society, 62, 607-614. http://dx.doi.org/10.1111/jgs.12749

[150] Aguiar, E.J., Morgan, P.J., Collins, C.E., Plotnikoff, R.C. and Callister, R. (2014) Efficacy of Interventions That Include Diet, Aerobic and Resistance Training Components for Type 2 Diabetes Prevention: A Systematic Review with Meta-Analysis. International Journal of Behavioral Nutrition and Physical Activity, 11, 2.

[151] Halse, R.E., Wallman, K.E., Newnham, J.P. and Guelfi, K.J. (2014) Home-Based Exercise Training Improves Capillary Glucose Profile in GDM Women. Medicine \& Science in Sports \& Exercise, 46, 1702-1709. http://dx.doi.org/10.1249/MSS.0000000000000302

[152] Sardar, M.A., Boghrabadi, V., Sohrabi, M., Aminzadeh, R. and Jalalian, M. (2014) The Effects of Aerobic Exercise Training on Psychosocial Aspects of Men with Type 2 Diabetes Mellitus. Global Journal of Health Science, 6, 196202.

[153] Balducci, S., Vulpiani, M.C., Pugliese, L., D’Errico, V., Menini, S., Salerno, G., Gargiulo, L., Ferretti, A. and Pugliese, G. (2014) Effect of Supervised Exercise Training on Musculoskeletal Symptoms and Function in Patients with Type 2 Diabetes: The Italian Diabetes Exercise Study (IDES). Acta Diabetologica, 51, 647-654.

[154] Moura, B.P., Amorim, P.R., Silva, B.P., Franceschini, S.C., Reis, J.S. and Marins, J.C. (2014) Effect of a Short-Term Exercise Program on Glycemic Control Measured by Fructosamine Test in Type 2 Diabetes Patients. Diabetology \& Metabolic Syndrome, 11, 16. http://dx.doi.org/10.1186/1758-5996-6-16

[155] Bursać, B.N., Vasiljević, A.D., Nestorović, N.M., Veličković, N.A., Vojnović Milutinović, D.D., Matić, G.M. and Djordjevic, A.D. (2014) High-Fructose Diet Leads to Visceral Adiposity and Hypothalamic Leptin Resistance in Male Rats-Do Glucocorticoids Play a Role? Journal of Nutritional Biochemistry, 25, 446-455. http://dx.doi.org/10.1016/j.jnutbio.2013.12.005

[156] Monteiro, P.F., Morganti, R.P., Delbin, M.A., Calixto, M.C., Lopes-Pires, M.E., Marcondes, S., Zanesco, A. and Antunes, E. (2012) Platelet Hyperaggregability in High-Fat Fed Rats: A Role for Intraplatelet Reactive-Oxygen Species Production. Cardiovascular Diabetology, 11, 5. http://dx.doi.org/10.1186/1475-2840-11-5

[157] Delbin, M.A. and Trask, A.J. (2014) The Diabetic Vasculature: Physiological Mechanisms of Dysfunction and Influence of Aerobic Exercise Training in Animal Models. Life Sciences, 102, 1-9. http://dx.doi.org/10.1016/j.lfs.2014.02.021

[158] Rao, X., Zhong, J., Xu, X., Jordan, B., Maurya, S., Braunstein, Z., Wang, T.Y., Huang, W., Aggarwal, S., Periasamy, M., Rajagopalan, S., Mehta, K. and Sun, Q. (2013) Exercise Protects Against Diet-Induced Insulin Resistance through Downregulation of Protein Kinase C $\beta$ in Mice. PLoS One, 8, e81364. http://dx.doi.org/10.1371/journal.pone.0081364

[159] Mizutani, K., Sonoda, S., Wakita, H., Katoh, Y. and Shimpo, K. (2014) Functional Recovery and Alterations in the 
Expression and Localization of Protein Kinase C Following Voluntary Exercise in Rat with Cerebral Infarction. Neurological Sciences, 35, 53-59. http://dx.doi.org/10.1007/s10072-013-1477-7

[160] Mizutani, K., Sonoda, S., Yamada, K., Beppu, H. and Shimpo, K. (2011) Alteration of Protein Expression Profile Following Voluntary Exercise in the Perilesional Cortex of Rats with Focal Cerebral Infarction. Brain Research, 1416, 61-68. http://dx.doi.org/10.1016/j.brainres.2011.08.012

[161] Meeusen, R. (2014) Exercise, Nutrition and the Brain. Sports Medicine, 44, 47-56. http://dx.doi.org/10.1007/s40279-014-0150-5

[162] Garcia, D. and Archer, T. (2014) Positive Affect and Age as Predictors of Exercise Compliance. PeerJ, 2 , e694. http://dx.doi.org/10.7717/peerj.694

[163] Archer, T. and Garcia, D. (2014) Physical Exercise Influences Academic Performance and Well-Being in Children and Adolescents. International Journal of School and Cognitive Psychology, 1, e102.

[164] Archer, T. and Garcia, D. (2015) Physical Exercise Improves Cognition in Brain Disorders: Alzheimer’s Disease. In: Farooqui, T. and Farooqui, A., Eds., Diet and Exercise in Cognitive Function and Neurological Diseases, WileyBlackwell Publishing, London, 175-181.

[165] Archer, T., Garcia, D. and Fredriksson, A. (2014) Restoration of MPTP-Induced Deficits by Exercise and Milmed ${ }^{\circledR}$ Co-Treatment. PeerJ, 2, e531. http://dx.doi.org/10.7717/peerj.531

[166] Garcia, D. and Archer, T. (2014) The Archer Ratio: A Measure of Exercise Behavior. 2nd Meeting of the Network for Empowerment and Well-Being, Gothenburg, 18 December 2013. 
Scientific Research Publishing (SCIRP) is one of the largest Open Access journal publishers. It is currently publishing more than 200 open access, online, peer-reviewed journals covering a wide range of academic disciplines. SCIRP serves the worldwide academic communities and contributes to the progress and application of science with its publication.

Other selected journals from SCIRP are listed as below. Submit your manuscript to us via either submit@scirp.org or Online Submission Portal.
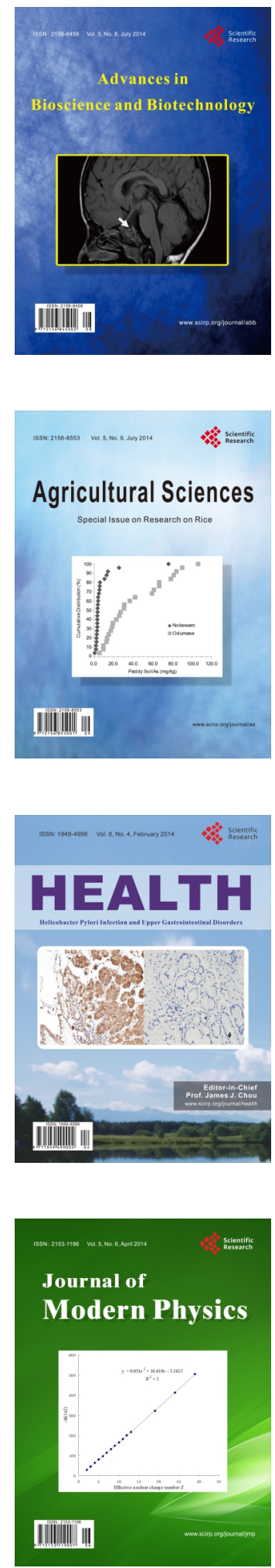
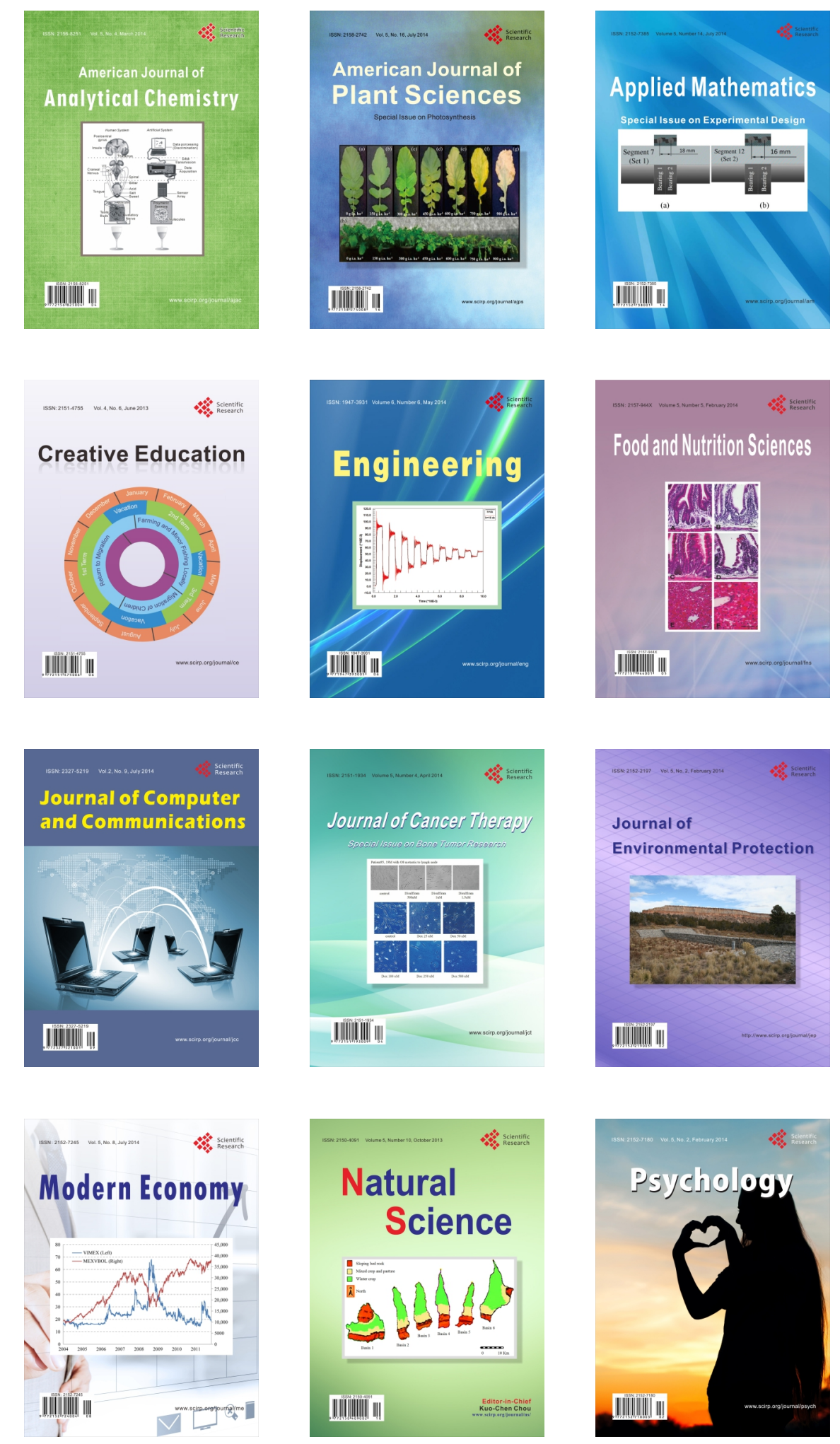